\title{
Lightweight concrete with coarse aggregate from ceramic waste at high temperatures
}

\section{Concreto leve com agregado graúdo proveniente de resíduo cerâmico sob elevadas temperaturas}
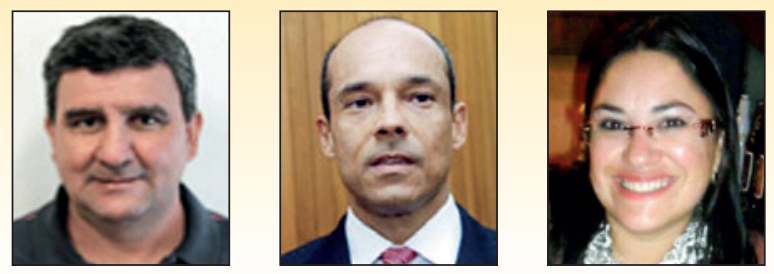

PASSOS a

lupa1602@unicamp.br https://orcid.org/0000-0002-1477-1880

A. L. MORENO JR. a armoreno@unicamp.br https://orcid.org/0000-0002-7660-050X

A. A. A. SOUZA b

adriana.souza@.sj.unisal.br https://orcid.org/0000-0002-6486-2828

\begin{abstract}
With the increasing use of recycled materials from civil construction, mainly as substitute for some aggregates in concrete mixtures, it is necessary to obtain technical information on the performance of these new mixtures. National and international research on the use of ceramic waste in concrete production highlight good results of this new material's mechanical performance in environmental situations. However, little is known about its behavior at high temperatures. In this context, we sought to verify the performance of concrete mixtures produced with aggregates from ceramic block waste at high temperatures, with evaluation of their residual mechanical strength, axial compressive strength and elastic modulus, and also their tendency to spalling in fire situations. The RILEM-129 MHT method [1] was used for the assessment of residual mechanical strength, and the tendency to spalling was evaluated according to the procedure suggested by Souza and Moreno [2]. In both these evaluations, there is no national standard, and, in the case of spalling, not even an international standard. Three concrete mixtures were used, one prepared with natural coarse basalt aggregate (reference) and the other two by replacing part of this natural aggregate with aggregate from ceramic block waste (40\% and $100 \%$ of substitution in volume). In the end, it is concluded that the substitution of natural coarse aggregate for lightweight aggregate from ceramic block waste can be an excellent alternative to increase the resistance of concrete to fire. Thus, the results of mechanical strength and spalling in a fire situation, unprecedented in our country, can greatly support the decision-making about the use of this alternative material in the national construction industry.
\end{abstract}

Keywords: concrete, waste, dosage, fire.

\section{Resumo}

Com o uso crescente de materiais reciclados provenientes da construção civil, principalmente como substituição de parte dos agregados em misturas de concreto, torna-se necessário suprir o meio técnico com informações sobre o desempenho destas novas misturas. Resultados de pesquisas, nacionais e internacionais, disponíveis quanto ao emprego de resíduos cerâmicos na produção de concreto, ressaltam bons resultados de desempenho mecânico deste novo material em situação ambiente. Entretanto, no que diz respeito ao desempenho sob elevadas temperaturas, pouco se conhece do comportamento deste material. Neste contexto, buscou-se verificar o desempenho às elevadas temperaturas de misturas de concreto produzidas com agregados provenientes de resíduos de blocos cerâmicos; com avaliação da resistência mecânica residual quando exposto às elevadas temperaturas - resistência à compressão axial e módulo de deformação e, também, o comportamento destas misturas quanto à tendência ao lascamento em situação de incêndio. Na avaliação da resistência mecânica residual foi empregado o método RILEM-129 MHT [1] e, a tendência ao lascamento foi avaliada segundo procedimento sugerido por Souza e Moreno [2]. Em ambas, as citadas avaliações, não existe padrão nacional normatizado e, no caso do lascamento, nem mesmo internacional. Foram empregadas três misturas de concreto, uma preparada com agregado graúdo natural de basalto (referência) e outras duas com substituição de parte deste agregado natural por agregado proveniente de resíduos de blocos cerâmicos (substituição de $40 \%$ e de $100 \%$ em volume). Ao final, conclui-se que a substituição de agregado graúdo natural por agregado leve, proveniente de resíduo de blocos cerâmicos, pode ser uma excelente alternativa de incremento de desempenho do concreto ao fogo. Desta forma, os resultados de resistência mecânica e de lascamento, em situação de incêndio, inéditos em nosso país, podem auxiliar sobremaneira o meio técnico científico nacional na tomada de decisões quanto ao emprego deste material, alternativo, na indústria da construção civil nacional.

Palavras-chave: concreto, resíduos, dosagem, incêndio. 


\section{Introduction}

Due to population growth, humanity is currently facing the problem of the generation of large amounts of garbage and waste. Much of this discarded material can and should be recycled. Although there are few national recycling and reuse programs, especially for ceramic waste (Campos and Paulon [3]), there has been an increase in the search for solutions to reduce this environmental impact and preserve natural resources, with national and international research focused on the development of methods and technologies for the reuse of some of these ceramic wastes in the construction industry. According to Campos and Paulon [3], the ceramic industry has a high rate of material disposal during the process of manufacture, transportation and possible replacement of ceramic bricks, coatings, sanitary wares and electric porcelain insulators. Given this context, it is necessary to study the reuses of this material, one of them being the use of this ceramic waste as coarse aggregate in the production of concrete for structural purposes. In this case, the structural elements manufactured with these alternative concrete mixtures must meet the necessary design parameters, aiming, above all, at the buildings' safety, both in environmental and fire situations.

Several authors $[4,5,6,7,8,9]$ have studied the possible replacement of natural aggregates with recycled ceramic materials and construction and demolition waste in environmental situations. In all the consulted works, the authors conclude that the reduction in the compressive strength of concrete is directly proportional to the increase in the percentage of substitution of natural with recycled aggregate, and that, even with this reduction, the substitution of natural aggregate with aggregate from ceramic waste may be viable, with favorable results even in relation to the mechanical performance of concrete for structural purposes.

Regarding the performance of this alternative concrete mixture in fire conditions, there are few results available in the international literature consulted and, it should be noted, they are nonexistent at the national level. In light of the above, this work aims to evaluate the residual mechanical strength of lightweight concrete produced with coarse aggregates from red ceramic waste at high temperatures, and to verify this mixture's tendency to explosive spalling.

\section{Residual mechanical strength of common and lightweight concrete at high temperatures}

Cânovas [10] points out that the effect of fire on concrete structures is directly correlated with the behavior of the materials making up the mixture. The physical, mechanical and thermal properties of the components of concrete control the mixture's response to high temperatures, and the type of coarse aggregate is one of the conditioning parameters of this behavior (Mehta e Monteiro [11]) Neville [12] states that: the loss in mechanical strength suffered by richer mixtures after exposure to high temperatures is greater than that suffered by mixtures with lower cement consumption; mixtures composed of aggregates with lower density tend to have greater residual mechanical strength than those composed of aggregates with higher density; concretes with high compressive strength have lower compressive strength after heating than mixtures with com- mon strength, and; the residual mechanical strength of saturated concrete is lower than that of dry concrete.

It should be noted that, currently, given the importance of the "coarse aggregate type" parameter in the response of concrete to fire, national and international normative codes such as NBR 15200 [13], ACI 216R-89 [14] and EUROCODE 1 [15] make it the only parameter for differentiating the mechanical behavior of concrete mixtures at high temperatures, to the detriment of parameters as important as compressive strength class, moisture content and even porosity. There are so many parameters involved in the response of concrete to fire that there is a large dispersion of national and international results, in relation to residual mechanical strength after heating, when these results are evaluated in light of a single parameter: the type of aggregate. The national results available in the literature have a percentage of significant differences as high as $70 \%[16,17]$.

These differences can be partly explained by the variation in the methodology of evaluation of residual mechanical strength in the laboratory. Nationally, there is no standardized procedure, while internationally, the standard is the RILEM-129 MHT method: Test Methods for Mechanical Properties of Concrete at High Temperatures (1995) [1].

Not all types of aggregates are referenced in these normative codes, which are restricted to presenting the increase in residual mechanical strength with temperature of concretes produced with silica and calcareous aggregates [13, 14 e 15].

In the case of concrete produced with lightweight aggregates, only ACl 216R-89 [14] references it. This fact may be explained by the scarcity of national or international research on the subject. Some of these studies are presented below.

Souza and Moreno [18] studied the reduction in compressive strength with the increase in temperature of concrete prepared with expanded clay, submitted to temperatures of $300^{\circ} \mathrm{C}$ and $600^{\circ} \mathrm{C}$, according to the International Organization for Standadization's Standard Curve - ISO 834 [19]. At the end, the authors conclude that the residual strength of concrete prepared with expanded clay is very close to the values referenced by the international normative codes for lightweight concrete.

Laneyrie et al. [20] evaluated the residual mechanical strength of concretes made from recycled aggregates after exposure to temperatures of $750^{\circ} \mathrm{C}$. Three mixtures with a water/cement ratio of 0.6 were used, in addition to three with a ratio of 0.3 . For each water/ cement ratio, a mixture with natural aggregate, another with aggregate from recycled concrete, and a third with aggregates from construction and demolition waste was produced. The mechanical test samples were cylindrical, with $110 \mathrm{~mm}$ in diameter and $220 \mathrm{~mm}$ in height. The heating temperatures were $20^{\circ} \mathrm{C}, 150^{\circ} \mathrm{C}, 300^{\circ} \mathrm{C}, 450^{\circ} \mathrm{C}$, $600^{\circ} \mathrm{C}$ and $750^{\circ} \mathrm{C}$, and the heating rate was $0.5^{\circ} \mathrm{C}$ per minute; once the desired temperature was reached, it was maintained for two hours. In this study, the authors concluded that residual mechanical strength was not very affected by the type of coarse aggregate used. Toric et al. [21] developed four mixtures of lightweight concrete with $100 \%$ expanded clay, used as fine and coarse aggregate, with the aim of analyzing their post-fire mechanical properties immediately after cooling and up to 96 hours after cooling, according to RILEM TC 129-MHT [1]. The sample used was cylindrical, with $75 \mathrm{~mm}$ in diameter and $225 \mathrm{~mm}$ in height, and the test temperatures were 
$20,200,400$ and $600^{\circ} \mathrm{C}$. The heating rate was $2.5^{\circ} \mathrm{C} / \mathrm{min}$, the heating plateau was 2.5 hours, and cooling was slow, at a rate of $1^{\circ} \mathrm{C} /$ min. The results showed significant differences of up to $59.7 \%$ for residual mechanical strength with a cooling time of 96 hours, and of $48.9 \%$ immediately after cooling when heated to $600^{\circ} \mathrm{C}$.

Martins et al [22] studied the post-heating residual mechanical strength of a concrete mixture made with natural aggregates, and of three concrete mixtures made with ceramic brick waste, with substitution percentages of 20,50 and $100 \%$. Cylindrical samples with $150 \mathrm{~mm}$ in diameter and $300 \mathrm{~mm}$ in height were produced for elastic modulus tests, and $150 \mathrm{~mm}$ cubic samples were produced for axial compressive strength tests. The heating temperatures were 200,400 and $600^{\circ} \mathrm{C}$, the heating rate was $2.5^{\circ} \mathrm{C} / \mathrm{min}$, the heating plateau was 1 hour and cooling was slow, at a rate of $1.5^{\circ} \mathrm{C} / \mathrm{min}$. These values were chosen as an approximation to the RILEM TC 129-MHT recommendation [1]. At the end, the authors note that the residual mechanical strength of concrete mixtures produced with ceramic aggregates was higher than the reference mixture, those with higher substitution percentages having achieved the best results.

Rajawat et al. [23] also studied mixtures of concrete with ceramic waste sand from sanitary ware, with substitution rates of 50 and $100 \%$. The samples used in the compressive strength tests were cubic, with $100 \mathrm{~mm}$ edges. The test temperatures were $200^{\circ} \mathrm{C}$, $500^{\circ} \mathrm{C}$ and $800^{\circ} \mathrm{C}$, at a heating rate of $5^{\circ} \mathrm{C}$ per minute, and an exposure time of 1 hour. At the end, the authors note that the loss of mechanical strength with the increase in temperature is lower for concretes produced with ceramic waste sand, compared to those produced with natural sand.

Yan et al. [24] produced cylindrical concrete samples with $50 \mathrm{~mm}$ in diameter and $50 \mathrm{~mm}$ in height using recycled aggregates, and evaluated their residual mechanical strength after heating. Three types of waste were used in the form of fine aggregate, one made of polypropylene, one of glass and one of Styrofoam, and only the aggregate from construction and demolition waste was used as coarse aggregate. The samples were heated to temperatures of $300^{\circ} \mathrm{C}, 500^{\circ} \mathrm{C}$ and $800^{\circ} \mathrm{C}$, at a rate of $2.5^{\circ} \mathrm{C} / \mathrm{min}$, and with exposure time of 4 hours. At the end, the authors conclude that the residual mechanical strength is lower for mixtures with coarse aggregates from construction and demolition waste and $100 \%$ of fine aggregates from glass waste, reaching $84 \%$.

An overview of the international results on the residual mechanical strength of lightweight concrete mixtures made with alternative materials after heating is presented, and it is important to highlight the significant difference between them. This fact justifies this work, the results of which will be added to the existing ones, contributing to a better understanding of the behavior of these alternative lightweight concretes at high temperatures.

\section{Spalling of common and lightweight concrete at high temperatures}

Another current concern regarding concrete in fire conditions is the spalling phenomenon, characterized by the detachment of parts of the concrete's heated surface and which can thus contribute to the acceleration of the structure's destruction during a fire. This spalling, when explosive, with sudden and violent detachment of a surface layer of concrete, has been observed by several authors over the years [25-32].

According to Souza and Moreno [2], among the various parameters involved in spalling, the type of coarse aggregate of the concrete mixture can be highlighted as one of the most relevant, lightweight concrete being more prone to the phenomenon than concrete with common density.

Also according to Souza and Moreno [2], there is no standardized test procedure for the laboratory evaluation of the tendency to explosive spalling of concrete. Nothing is yet established regarding sample size, sample preparation (execution and cure), temperature exposure time, heating rate, or quantification of the phenomenon (sample degradation in terms of cracking and detachment of the surface layer). The authors describe in their work a method for verifying the spalling of concrete using slab-shaped samples taken from a prismatic specimen, $150 \mathrm{~mm}$ high, $150 \mathrm{~mm}$ wide and $500 \mathrm{~mm}$ long. In the international technical literature, there are several research papers on the spalling of concrete at high temperatures [25 to 32]. In these works, the sample size, heating rate, moisture content, maximum exposure temperature, the existence or not of steel reinforcement, and even the test methodology are very different, making it difficult to carefully evaluate the results so as to predict the phenomenon. There is a consensus that a full-scale assessment of the phenomenon is practically economically unfeasible, resulting in the proposition of methodologies using small-sized samples, evaluated in small gas $[28,29,30]$ or electric [31] furnaces.

Concerning the spalling of heated concrete produced with lightweight or recycled aggregates, the research results found in the international literature are scarce and described below.

$\mathrm{Ke}$ Cheng $\mathrm{He}$ et al. [33], evaluated the spalling of lightweight concrete produced with expanded clay. Four concrete mixtures were evaluated, a reference one made with limestone coarse aggregate, one made with expanded clay, another mixture identical to the second, made from expanded clay and waterproofed using products from the region, and the last mixture also identical to the second, made from expanded clay and waterproofed using another type of product from the region that was not mentioned in the work. For all mixtures, $100 \times 100 \times 300 \mathrm{~mm}$ prisms were molded and heated on both sides to $200^{\circ} \mathrm{C}, 400^{\circ} \mathrm{C}, 600^{\circ} \mathrm{C}, 800^{\circ} \mathrm{C}, 1000^{\circ} \mathrm{C}$ and $1200^{\circ} \mathrm{C}$ at a heating rate of $10^{\circ} \mathrm{C}$ per minute. At the end, the authors report that spalling was not observed for mixtures made from expanded clay with waterproofed surfaces, and that it was observed for the other mixtures at temperatures above $400^{\circ} \mathrm{C}$. The quantification of spalling was carried out visually and by measuring weight loss. Laneyrie et al. [19], investigated the spalling phenomenon in concrete mixtures produced with recycled aggregates. Three mixtures with a water/cement ratio of 0.6 were used, in addition to three with a ratio of 0.3 . For each water/cement ratio, one concrete sample made with aggregate from natural limestone, another with aggregate from recycled concrete, and another with aggregate from construction and demolition waste was produced. The samples had $160 \mathrm{~mm}$ in diameter and $50 \mathrm{~mm}$ in thickness and were heated on one side only. The heating temperatures were $20^{\circ} \mathrm{C}, 150^{\circ} \mathrm{C}, 300^{\circ} \mathrm{C}, 450^{\circ} \mathrm{C}, 600^{\circ} \mathrm{C}$ and $750^{\circ} \mathrm{C}$, and the heating rate was $0.5^{\circ} \mathrm{C}$ per minute; once the desired temperature was reached, it was maintained for two hours. At the end, the authors report that there was no spalling of any of the samples produced with recycled aggregates. 
Table 1

Mix proportions with and without waste

\begin{tabular}{ccccccc}
\hline Mixture & $\begin{array}{c}\text { Cement } \\
(\mathrm{kg})\end{array}$ & $\begin{array}{c}\text { Natural fine } \\
\text { aggregate } \\
(\mathrm{kg})\end{array}$ & $\begin{array}{c}\text { Natural coarse } \\
\text { aggregate } \\
\text { (liters) }\end{array}$ & $\begin{array}{c}\text { Ceramic coarse } \\
\text { aggregate } \\
\text { (liters) }\end{array}$ & w/c & $\begin{array}{c}\text { Slump } \\
(\mathrm{mm})\end{array}$ \\
\hline REF & 1 & 2 & 1.7 & 0 & 0.49 & 50 \\
S40 & 1 & 2 & 1.0 & 0.7 & 0.49 & 50 \\
S100 & 1 & 2 & 0 & 1.7 & 0.49 & 50 \\
\hline
\end{tabular}

Martins et al. [22], evaluated the possible spalling of $150 \mathrm{~mm}$ cubic concrete samples produced with coarse aggregates from ceramic brick waste. The heating temperatures were 200,400 and $600^{\circ} \mathrm{C}$, and the heating rate ranged from 1.5 to $2.5^{\circ} \mathrm{C} / \mathrm{min}$, in line with RILEM TC 129-MHT [1]. As a result, the authors report minor spalling in samples subjected to $600^{\circ} \mathrm{C}$.

Bodnóravá et al. [34], evaluated the possible spalling of 100×300×1050 $\mathrm{mm}$ concrete slabs produced with expanded clay and exposed to temperatures up to $1050^{\circ} \mathrm{C}$, according to the International Organization for Standardization's Standard Curve — ISO 834 [19]. At the end, the authors note that spalling occurred at temperatures above $700^{\circ} \mathrm{C}$, and that the moisture content of the samples with lightweight aggregate must be below $10 \%$ to avoid spalling, because the presence of moisture causes the aggregate to rupture.

Given the above, it is noted that much remains to be done to evaluate the spalling of concrete in a fire situation. With regard to concretes produced with lightweight or recycled aggregates, there is an even longer way to go before the phenomenon can be explained and quantified. This work attempts to take some steps in this direction, evaluating the spalling of concrete mixtures with lightweight aggregates from ceramic block waste at high temperatures.

\section{Materials and experimental program}

\subsection{Concrete mixtures}

For this work, three concrete mixtures were produced (Table [1]), one with natural aggregate (REF), and two with $40 \%$ and $100 \%$ of substitution (S40 and S100) of the natural aggregate for aggregates from recycled ceramic waste. The water-cement ratio was set at 0.49 for all mixtures.

\subsection{Properties of the materials used}

The characteristics of the aggregates employed in this work are presented in Table [2].

The conventional coarse aggregate had gravel with diameters ranging from $9.5 \mathrm{~mm}$ to $25 \mathrm{~mm}$. The recycled coarse aggregate was obtained by grinding the waste from tile/ceramic block factories in the region of Campinas/SP.

The cement used was CP II E32, composed of $10 \%$ blast furnace slag, frequently used in small works and common in the region of Campinas/SP.

\subsection{Evaluation of residual compressive strength and elastic modulus}

For each concrete mixture evaluated, 40 cylindrical samples with $100 \mathrm{~mm}$ in diameter and $300 \mathrm{~mm}$ in height were analyzed to verify the residual mechanical properties after heating up to 200,400 , 600 and $800^{\circ} \mathrm{C}$. The samples were heated in an ML 1300/60 furnace with a maximum heating temperature of $1300^{\circ} \mathrm{C}$ belonging to the Laboratory of Structures and Building Materials of UNICAMP's School of Civil Engineering, Architecture and Urbanism (FEC).

The methodology used followed RILEM-129 MHT: Test Methods for Mechanical Properties of Concrete at High Temperatures

Table 2

Physical properties of the materials used

\begin{tabular}{|c|c|c|c|}
\hline Property & $\begin{array}{l}\text { Ceramic waste } \\
\text { aggregate }\end{array}$ & $\begin{array}{l}\text { Conventional } \\
\text { coarse aggregate }\end{array}$ & Fine aggregate \\
\hline $\begin{array}{l}\text { Bulk specific gravity }\left(\mathrm{g} / \mathrm{cm}^{3}\right) \\
\text { NBR NM } 53 \text { [35], NM } 52[36]\end{array}$ & 1.77 & 2.89 & 2.63 \\
\hline $\begin{array}{l}\text { C.M.D. }(\mathrm{mm}) \\
\text { NBR NM } 248 \text { [39] }\end{array}$ & 19 & 19 & 4.8 \\
\hline $\begin{array}{l}\text { F.M. }(\mathrm{mm}) \\
\text { NBR NM - } 248 \text { [39] }\end{array}$ & 6.41 & 6.86 & 2.4 \\
\hline $\begin{array}{l}\text { Unit weight }\left(\mathrm{g} / \mathrm{cm}^{3}\right) \\
\text { NBR NM } 45[38]\end{array}$ & 0.95 & 1.62 & 1.47 \\
\hline $\begin{array}{l}\text { Clods of clay and friable materials (\%) } \\
\text { NBR } 7218[41]\end{array}$ & 0 & 0 & 0 \\
\hline $\begin{array}{l}\text { Rate of material passing through the sieve } 75 \mu \mathrm{m}(\%) \\
\text { NBR NM } 46[40]\end{array}$ & - & 0.69 & 2.37 \\
\hline $\begin{array}{l}\text { Water absorption (\%) } \\
\text { NBR NM } 53 \text { [35], NM } 30 \text { [37] }\end{array}$ & 19 & 1.2 & 0.15 \\
\hline
\end{tabular}




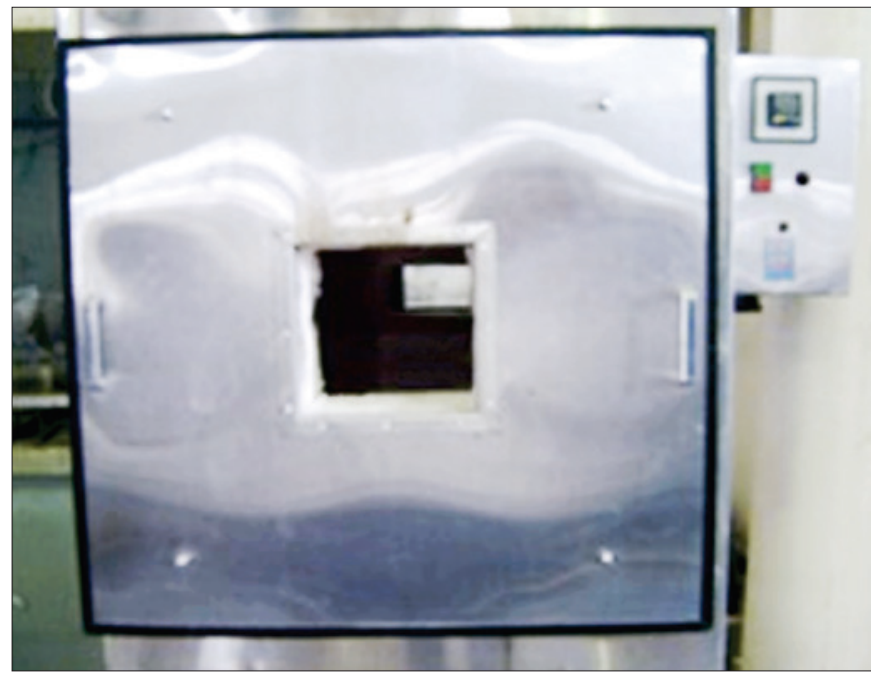

Figure 1a

Furnace for heating the samples and used in the evaluation of spalling

(1995) [1], which adopts a heating and cooling rate of $1^{\circ} \mathrm{C}$ per minute, with the sample being kept for 60 minutes at the temperature of interest. The choice of this methodology aims at the internationalization of evaluations, so that it is possible to compare national and international results.

The concrete samples' residual compressive strength was determined according to RILEM TC 129-MHT Part 3 [42], by applying a uniaxial compression load towards the central axis at a rate of 0.5 MPa per second. The samples' elastic modulus was determined according to RILEM TC 129-MHT Part 5 [43].

\subsection{Evaluation of explosive spalling}

At this stage of the work, it was sought to evaluate the possible spalling of the concrete mixtures when subjected to the Interna-

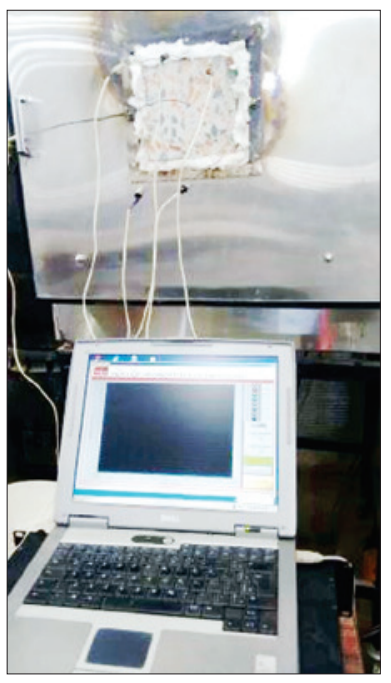

Figure 1b

Sample positioned for the evaluation of spalling

tional Organization for Standardization's Standard Curve - ISO 834 [19] for 60 minutes until reaching a temperature of $925^{\circ} \mathrm{C}$.

In the absence of a standardized national or international procedure, the procedure employed was the one proposed by Souza and Moreno [18], which consists in heating one side of a prismatic $150 \times 150 \mathrm{~mm}$ cross-sectional sample with $100 \mathrm{~mm}$ thickness. The heating was carried out when the samples turned 100 days old. Before heating, they were placed in an oven at a temperature of $100^{\circ} \mathrm{C}$ until reaching a constant weight. After this stage, one side was saturated in water and heated.

The samples were heated in a furnace belonging to the Laboratory of Structures and Building Materials of UNICAMP's School of Civil Engineering, Architecture and Urbanism (FEC), Figure [1a] and Figure [1b]. Each sample was placed in a front door of the equipment and sealed with a glass wool blanket. The temperature of

Table 3

Mix proportions with and without waste

\begin{tabular}{|c|c|c|c|c|c|}
\hline REF & $0^{\circ} \mathrm{C}$ & $200^{\circ} \mathrm{C}$ & $400^{\circ} \mathrm{C}$ & $600^{\circ} \mathrm{C}$ & $800^{\circ} \mathrm{C}$ \\
\hline $\begin{array}{c}f_{c}(\mathrm{MPa}) \\
\text { Reduction \% }\end{array}$ & $\begin{array}{c}40.62 \\
100\end{array}$ & $\begin{array}{c}32.12 \\
79\end{array}$ & $\begin{array}{c}24.06 \\
59\end{array}$ & $\begin{array}{c}11.17 \\
28\end{array}$ & $\begin{array}{l}7.83 \\
19\end{array}$ \\
\hline $\begin{array}{c}\mathrm{E}_{\mathrm{c}}(\mathrm{GPa}) \\
\text { Reduction \% } \\
\end{array}$ & $\begin{array}{c}31.75 \\
100 \\
\end{array}$ & $\begin{array}{c}26.45 \\
83 \\
\end{array}$ & $\begin{array}{l}8.35 \\
26 \\
\end{array}$ & $\begin{array}{c}2.69 \\
8 \\
\end{array}$ & $\begin{array}{l}1.50 \\
5 \\
\end{array}$ \\
\hline S40 & $0^{\circ} \mathrm{C}$ & $200^{\circ} \mathrm{C}$ & $400^{\circ} \mathrm{C}$ & $600^{\circ} \mathrm{C}$ & $800^{\circ} \mathrm{C}$ \\
\hline $\begin{array}{c}\mathrm{f}_{\mathrm{c}}(\mathrm{MPa}) \\
\text { Reduction \% }\end{array}$ & $\begin{array}{c}19.83 \\
100\end{array}$ & $\begin{array}{c}19.61 \\
99\end{array}$ & $\begin{array}{c}15.41 \\
78\end{array}$ & $\begin{array}{c}13.11 \\
66\end{array}$ & $\begin{array}{l}4.39 \\
22\end{array}$ \\
\hline $\begin{array}{c}E_{c}(G P a) \\
\text { Reduction \% }\end{array}$ & $\begin{array}{c}14.50 \\
100 \\
\end{array}$ & $\begin{array}{c}14.58 \\
100 \\
\end{array}$ & $\begin{array}{c}4.41 \\
30 \\
\end{array}$ & $\begin{array}{c}2.24 \\
15 \\
\end{array}$ & $\begin{array}{c}0.81 \\
6 \\
\end{array}$ \\
\hline$S 100$ & $0^{\circ} \mathrm{C}$ & $200^{\circ} \mathrm{C}$ & $400^{\circ} \mathrm{C}$ & $600^{\circ} \mathrm{C}$ & $800^{\circ} \mathrm{C}$ \\
\hline $\begin{array}{c}f_{c}(\mathrm{MPa}) \\
\text { Reduction \% }\end{array}$ & $\begin{array}{c}16.44 \\
100\end{array}$ & $\begin{array}{c}13.38 \\
81\end{array}$ & $\begin{array}{c}12.59 \\
77\end{array}$ & $\begin{array}{c}6.97 \\
42\end{array}$ & $\begin{array}{c}3.31 \\
20\end{array}$ \\
\hline $\begin{array}{c}\mathrm{E}_{\mathrm{c}}(\mathrm{GPa}) \\
\text { Reduction \% }\end{array}$ & $\begin{array}{c}12.67 \\
100\end{array}$ & $\begin{array}{c}11.48 \\
91\end{array}$ & $\begin{array}{c}4.25 \\
34\end{array}$ & $\begin{array}{l}1.66 \\
13\end{array}$ & $\begin{array}{c}0.62 \\
5\end{array}$ \\
\hline
\end{tabular}




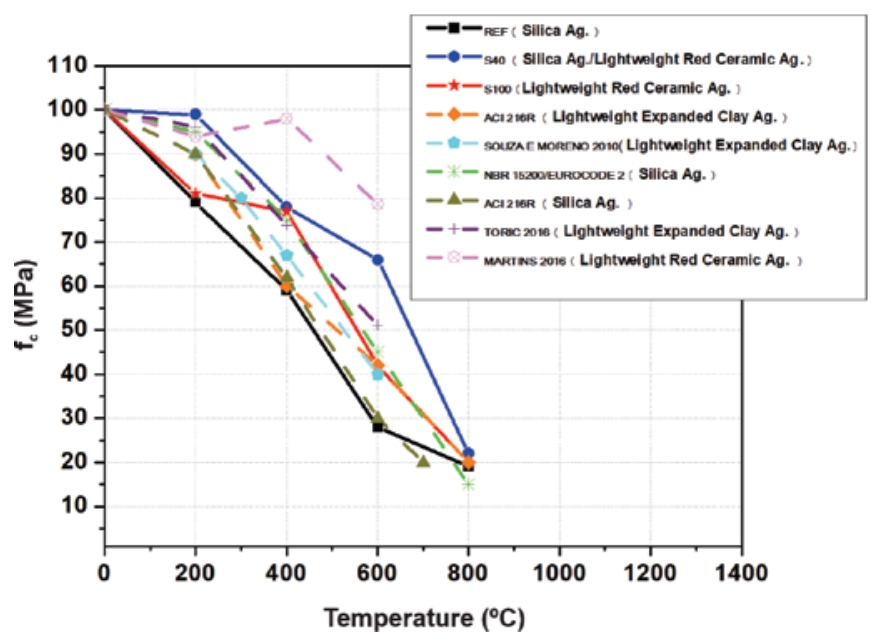

Figure 2

Reduction values of the axial compressive strength of concrete mixtures with substitution percentages of $0 \%, 40 \%$ and $100 \%$

the furnace and samples was controlled with thermocouples connected to an automatic data logger, positioned according to ISO 834 [19]. After heating, the samples were visually evaluated for spalling and cracking.

\section{Results and discussions}

\subsection{Residual compression strength}

As expected, the axial compressive strength values were found to decrease with the increase in the percentage of replacement of the coarse aggregate with red ceramic waste, and also with the increase in heating temperature (Table [3]). This reduction in mechanical strength at room temperature is attributed to the low density and mechanical strength of the recycled red ceramic aggregate compared to the natural aggregate.

Figure [2] presents the results of this research, the results obtained by the main researchers referenced in this work [18, 21 and 22] who used lightweight aggregates in the mixture, as well as the curves recommended by the relevant national and international codes. It should be noted that in the case of National Standard NBR 15200 [13] and EUROCODE 2 [15], the recommended values are inherent to concretes made of silica aggregates and, although the texts of these codes do not make this clear, they refer to unloaded samples ruptured by axial compression under heating, a load history which, admittedly, results in higher residual mechanical strength values than those obtained with unloaded samples tested after slow cooling. Figure [2], with a load history similar to that adopted in this research, also shows the evolution of the residual compressive strength of concrete samples made with lightweight expanded clay aggregates $\left(450 \mathrm{~kg} / \mathrm{m}^{3}\right.$ specific weight) recommended by $\mathrm{ACl}$ [14] and in relation to unloaded heated samples ruptured by axial compression after slow cooling.

Table 4 presents the geometric and methodological parameters employed by these codes and researchers under comparison.

In Figure [2], it can be seen that replacing the coarse aggregate with red ceramic waste results in concretes that are more resistant to fire, i.e., the strength losses for concretes with $40 \%$ and $100 \%$ of substitution are lower compared to the reference sample. This increase in the resistance to fire of concretes made with red ceramic waste, according to Martins et al [22], can be explained by the fact that the thermal expansion coefficient of red ceramic waste is much smaller than that of the natural aggregate, making the volumetric variations of this recycled aggregate compatible with the deformations in the matrix, resulting in lower internal stresses and consequently less cracking of the mixture with heating. Martins et al [22] also observed that aggregates from red ceramic waste are more stable at higher temperatures than aggregates of natural origins, and that, with the increase in temperature, the influence of the lower strength of red ceramic waste (compared to the natural aggregates) over the

\section{Table 4}

Comparative data of the test parameters (residual strength)

\begin{tabular}{|c|c|c|c|c|c|c|}
\hline & $\begin{array}{l}\% \text { of substitution } \\
\text { of the coarse } \\
\text { aggregate }\end{array}$ & $\begin{array}{l}\text { Heating } \\
\text { pattern }\end{array}$ & $\begin{array}{l}\text { Type of } \\
\text { heating }\end{array}$ & Cooling & $\begin{array}{l}\text { Type of } \\
\text { aggregate }\end{array}$ & $\begin{array}{l}\text { Sample } \\
\text { size }\end{array}$ \\
\hline REF & 0 & RILEM/ $/ 1^{\circ} \mathrm{C} / \mathrm{min}$ & Slow & No load & Basalt & $\begin{array}{l}\varnothing=100 \mathrm{~mm} \\
\mathrm{H}=300 \mathrm{~mm}\end{array}$ \\
\hline S40 & 40 & $\mathrm{RILEM} / 1^{\circ} \mathrm{C} / \mathrm{min}$ & Slow & No load & $\begin{array}{l}\text { Basalt/ } \\
\text { ceramic }\end{array}$ & $\begin{array}{l}\varnothing=100 \mathrm{~mm} \\
\mathrm{H}=300 \mathrm{~mm}\end{array}$ \\
\hline S100 & 100 & $\mathrm{RILEM} / 1^{\circ} \mathrm{C} / \mathrm{min}$. & Slow & No load & $\begin{array}{l}\text { Lightweight/ } \\
\text { ceramic }\end{array}$ & $\begin{array}{l}\varnothing=100 \mathrm{~mm} \\
\mathrm{H}=300 \mathrm{~mm}\end{array}$ \\
\hline $\mathrm{ACl} 216 \mathrm{R}$ & 100 & - & - & No load & Lightweight & $\begin{array}{l}\varnothing=100 \mathrm{~mm} \\
\mathrm{H}=300 \mathrm{~mm}\end{array}$ \\
\hline $\begin{array}{l}\text { Souza and } \\
\text { Moreno } 2010\end{array}$ & 100 & ISO 834. & Slow & No load & $\begin{array}{c}\text { Lightweight } \\
\text { (expanded clay) }\end{array}$ & $\begin{array}{l}\varnothing=100 \mathrm{~mm} \\
\mathrm{H}=200 \mathrm{~mm}\end{array}$ \\
\hline NBR/Eurocode & 100 & - & - & With load & Limestone & $\begin{array}{l}\varnothing=100 \mathrm{~mm} \\
H=200 \mathrm{~mm}\end{array}$ \\
\hline Toric 2017 & 100 & $\mathrm{RILEM} / 2.5^{\circ} \mathrm{C} / \mathrm{min}$. & Slow & No load & $\begin{array}{l}\text { Lightweight } \\
\text { (expanded clay) }\end{array}$ & $\begin{array}{l}\varnothing=75 \mathrm{~mm} \\
\mathrm{H}=225 \mathrm{~mm}\end{array}$ \\
\hline Martins 2016 & 100 & $\mathrm{RILEM} / 2.5^{\circ} \mathrm{C} / \mathrm{min}$. & Slow & No load & $\begin{array}{l}\text { Lightweight } \\
\text { (ceramic) }\end{array}$ & $\begin{aligned} \varnothing & =150 \mathrm{~mm} \\
\mathrm{H} & =300 \mathrm{~mm}\end{aligned}$ \\
\hline
\end{tabular}


compressive strength of concrete is lower, as it is progressively governed by the cementitious matrix, i.e., in mixtures with aggregates from red ceramic waste subjected to heating, the weaker part of the concrete is no longer the aggregate, but the cementitious matrix, which is basically similar in all concrete mixtures.

In this work, on the other hand, the residual strength of concrete produced with natural silica is lower than the recommended by NBR 15200 [13]. These results were expected, since the load history used in this research is different from the load history considered in NBR 15200 [13]. It is a well-known fact that unloaded heating and subsequent rupture after slow cooling results in lower residual compressive strengths. After cooling, the calcium oxide $(\mathrm{CaO})$ formed during heating is rehydrated, a largely expansive process which consequently contributes to the greater micro-cracking of concrete, thus resulting in lower residual strengths. Another factor that may contribute to the lower residual strength of heated and cooled concrete samples prior to the rupture caused by compression is the development of cracks on the region between the coarse aggregate and the cement paste, during the cooling process.

When comparing the results of the reference mixture of this research (REF) to the curve suggested by $\mathrm{ACl}$ [14], with coarse aggregate and load history resembling those of this work, it is noted that the evolution of residual compressive strength is very similar, reinforcing the existence of the influence highlighted in the previous paragraph.

On the other hand, the results of Martins et al [22], using ceramic aggregates that were similar to those used in this work, are more favorable, with greater residual mechanical strength after heating. This fact shows the great influence of the samples' geometry and of time of exposure to the desired temperature on the residual mechanical strength of concrete. Although with similar mix proportions, Martins et al [22] used larger samples, and heated them to the temperature of interest for less time than the samples in this work, thus resulting in a lower degree of deterioration. The importance of standardization of the samples' geometry, heating rate and exposure time for the results of residual compressive strength after heating can also be verified by observing those obtained by Souza and Moreno [18] and Toric et al [21], who used expanded clay as coarse aggregate, and very different heating rates. The heating rate used by Souza and Moreno [18] was 6 times higher than that employed by Toric et al [21]. A high temperature heating rate may lead to further deterioration of concrete with the increase in temperature, causing cracking and minor spalling, which may explain the more favorable results obtained by Toric et al [21] when compared to Souza and Moreno's [18].

Finally, it should be noted that the curve proposed by ACl 216 R89 [14] for concrete with lightweight aggregate from expanded clay, with $450 \mathrm{~kg} / \mathrm{m}^{3}$ specific weight, unloaded heating and rupture after slow cooling, shows residual mechanical strengths caused by the heating temperature being always lower than those observed for the lightweight concrete mixtures of this research and of the aforementioned researches. This fact may justify, in future revisions of NBR 15200 [13], the adoption of the ACI 216 R89 curve [14] for the behavior of lightweight concrete at high temperatures, at least while relevant national results of works similar to the ones presented are not obtained.

These results, unique in our country, should provide subsidies for a future understanding of the behavior of domestic lightweight concrete at high temperatures.

\subsection{Residual elastic modulus}

In Table [3] it can be observed, as occurred for compressive strength at room temperature, that the longitudinal elastic modulus of the concrete mixtures with substitution of natural aggregate for the recycled ceramic aggregate (S40 and S100) showed decreases in relation to the elastic modulus obtained for the reference sample (REF). The physical and mechanical properties of the coarse aggregate are noted to have great influence on the value of the elastic modulus of concrete made with this aggregate, as it almost always increased with the increase in the coarse aggregate's mechanical strength. The recycled ceramic aggregate employed in this research had much lower density and compressive strength than the natural aggregate employed in the reference mixture (REF), which justifies the decrease in the values of the elastic modules with the increase in the substitution of the natural aggregate for the ceramic aggregate.

Figure [3] presents the results of this research, the results obtained by the main researchers referenced in this work [18 and 22] who used lightweight aggregates in the mixture, as well as the curves recommended by the relevant national and international codes. It should be noted that, in the case of National Standard NBR 15200 [13] and EUROCODE 2 [15], the values given are inherent to concretes made with silica aggregates and, although the texts of these codes do not make this clear, they refer to unloaded samples ruptured by axial compression under heating, a load history which, admittedly, results in higher residual mechanical strength values than those obtained with unloaded samples tested after slow cooling. Figure [3] also shows the evolution of the residual elastic modulus of concrete samples made with silica aggregate and lightweight aggregate from expanded clay $\left(450 \mathrm{~kg} / \mathrm{m}^{3}\right.$ specific weight) recommended by $\mathrm{ACl}[14]$ and referring to unloaded samples ruptured

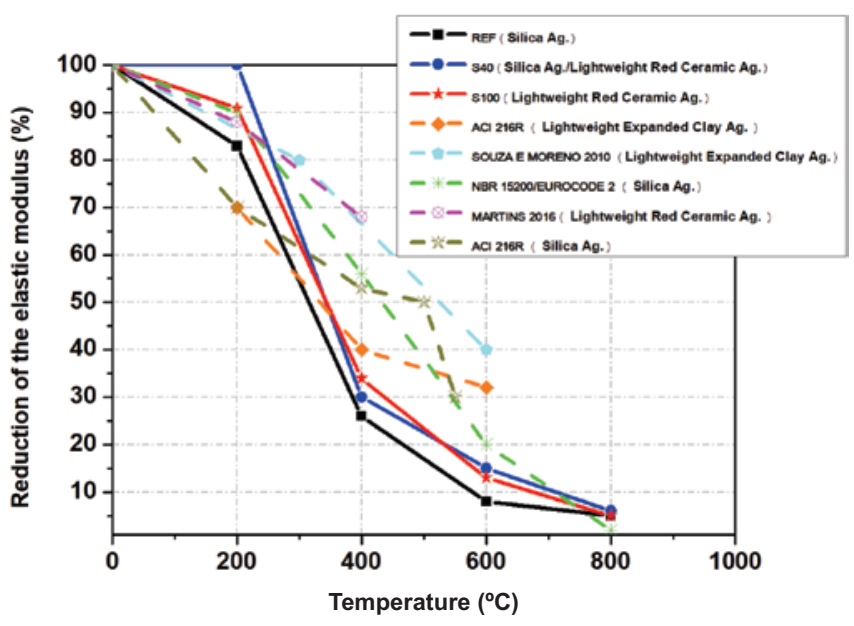

Figure 3

Reduction values of the elastic modulus of concrete mixtures with substitution percentages of $0 \%, 40 \%$ and $100 \%$ 
by axial compression under heating. Unlike the recommendations of $\mathrm{ACl}$ [14] for residual compressive strength, this normative code chose not to distinguish between load histories in the case of the residual elastic modulus of concrete after heating.

Table 4 presents the geometric and methodological parameters employed by these codes and researchers under comparison.

In Figure [3] it can be seen that replacing the coarse aggregate with red ceramic waste results in concretes that are more resistant to fire, i.e., the losses in the elastic modulus of concretes with 40 and $100 \%$ of substitution are lower when compared to the reference sample. This small increase in the residual elastic modulus, although much lower than that observed for the residual compressive strength of the same mixtures, can be explained in the same way, using the research by Martins et al [22].

As occurred for residual compressive strength, the residual elastic modulus of the concrete produced from natural silica aggregate of this work is smaller than the recommended by NBR 15200 [13] and $\mathrm{ACl} 216$ [14] for concretes made with this same aggregate. These results were already expected and can also be explained in the same way as the results for compressive strength, considering the different load history as an intervening parameter.

Comparing the results of this research with those of Martins et al [22], who used a ceramic aggregate similar to that of this work, shows that those obtained by Martins et al are quite favorable, with higher residual elastic modulus after heating. This fact highlights, once again, the great influence of the samples' geometry and of time of exposure to the desired temperature over the concrete's residual elastic modulus. Although with similar mix proportions, Martins et al [22] used larger samples, and heated them to the temperature of interest for less time than the samples in this work, thus resulting in a lower degree of deterioration. However, Martins et al [22] present the residual elastic modulus' results for heating temperatures up to $400^{\circ} \mathrm{C}$.

Finally, it should be noted that the same suggestion of these authors, using the curve proposed by ACl 216 R89 [14] for concrete with lightweight aggregates, should be reevaluated in a future revision of NBR 15200 [13] for the case of the residual elastic modulus. When comparing the results of this research with the curve suggested by
$\mathrm{ACl} 216 \mathrm{R}-89$ [14] for lightweight aggregates, it is noted that the evolution of the residual elastic modulus shows differences that should be highlighted. Starting at approximately $350^{\circ} \mathrm{C}$, the residual elastic modulus recommended by this normative code is greater, i.e., less conservative, than the results obtained in this work. It should be noted that the results available in the literature, which generated the curve recommended by $\mathrm{ACl} 216 \mathrm{R}-89$ [14] for the residual elastic modulus, were quite scarce at the time, possibly explaining the observed differences. Likewise, it should be noted that although in absolute numbers the results compared show differences of the order of $100 \%$, in relative numbers, this difference is very small $(30 \%$ against $15 \%$ at most), i.e., in this temperature range, the residual elastic modulus is very low, in any of the curves under comparison.

\subsection{Explosive spalling}

No spalling was observed, explosive or otherwise, in the concrete samples evaluated in this work. It was possible to observe (Figure [4]) that the concrete mixture with $100 \%$ of substitution of natural silica aggregate for the recycled red ceramic aggregate showed a less aggressive cracking panorama than the reference sample; however, no spalling occurred in any of the concretes tested, even at temperatures above $800^{\circ} \mathrm{C}$.

As noted earlier, with regard to the spalling of heated concretes produced from lightweight or recycled aggregates, the results found in the international literature are very scarce. Of the international works presented, spalling was observed in Ke Cheng $\mathrm{He}$ et al. [33], Bodnóravá et al. [34] and Martins et al [22]. In all these works, lightweight aggregates were used in the concrete mixture: expanded clay in the first two and recycled ceramic aggregate in the last. It is worth noting that spalling was observed in a small number of the samples evaluated, and for varying temperatures of evaluation; above $700^{\circ} \mathrm{C}$ in Bodnóravá et al. [34], above $400^{\circ} \mathrm{C}$ in Ke Cheng He et al. [33] and at $600^{\circ} \mathrm{C}$ in Martins et al [22].

Since there is no standardized test procedure for the laboratory evaluation of the tendency to explosive spalling of concrete, in these studies, the sample size, heating rate, moisture content, maximum

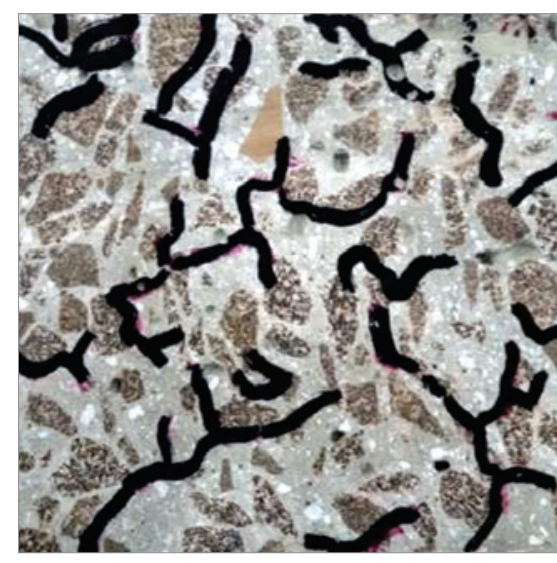

REF.

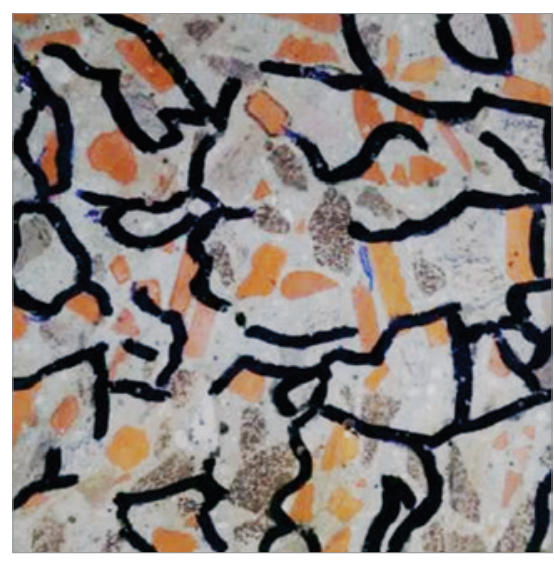

540

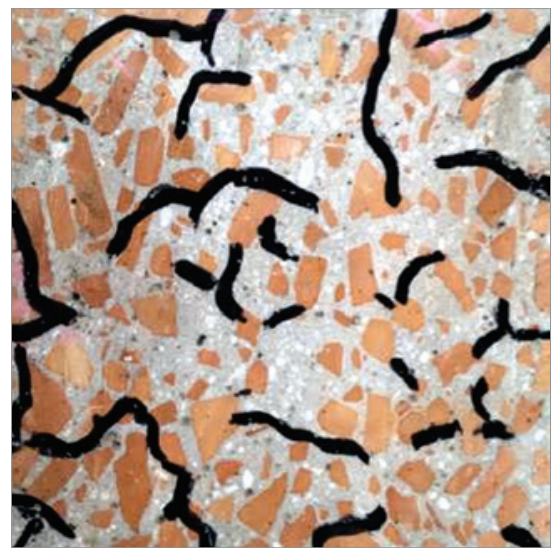

5100

Figure 4

Specimens after the evaluation of explosive spalling (temperature: $925^{\circ} \mathrm{C}$ ) 
Table 5

Comparative data of the test parameters (spalling)

\begin{tabular}{|c|c|c|c|c|c|c|c|}
\hline Author & $\begin{array}{l}\text { Substitution } \\
\text { rate } \\
(\%) \\
\end{array}$ & $\begin{array}{l}\text { Sample size } \\
(\mathrm{mm})\end{array}$ & $\begin{array}{c}\text { Type of } \\
\text { aggregate }\end{array}$ & $\begin{array}{l}\text { Heating } \\
\text { pattern }\end{array}$ & $\begin{array}{l}\text { Time of } \\
\text { exposure } \\
\text { (hours) }\end{array}$ & $\begin{array}{l}\text { Type of } \\
\text { analysis }\end{array}$ & Results \\
\hline REF & 0 & $150 \times 150 \times 100$ & Basalt & ISO 834 & 1 & Visual & No spalling \\
\hline S40 & 40 & $150 \times 150 \times 100$ & $\begin{array}{l}\text { Basalt/ } \\
\text { ceramic }\end{array}$ & ISO 834 & 1 & Visual & No spalling \\
\hline S100 & 100 & $150 \times 150 \times 100$ & $\begin{array}{l}\text { Lightweight/ } \\
\text { ceramic }\end{array}$ & ISO 834 & 1 & Visual & No spalling \\
\hline $\begin{array}{l}\text { Ke Cheng } \\
\text { He et al. }\end{array}$ & 100 & $100 \times 100 \times 300$ & $\begin{array}{c}\text { Expanded } \\
\text { clay }\end{array}$ & $\begin{array}{l}10^{\circ} \mathrm{C} \text { per } \\
\text { minute }\end{array}$ & 1 & $\begin{array}{l}\text { Visual and } \\
\text { aggregate } \\
\text { loss }\end{array}$ & $\begin{array}{l}\text { Spalling when } \\
\mathrm{T}>400^{\circ} \mathrm{C}\end{array}$ \\
\hline Laneyrie et al. & 100 & $\begin{array}{c}\phi 160 \mathrm{~mm} \\
\mathrm{~h}=50 \mathrm{~mm}\end{array}$ & $\begin{array}{l}\text { Construction } \\
\text { and } \\
\text { demolition } \\
\text { waste }\end{array}$ & $\begin{array}{l}0.5^{\circ} \mathrm{C} \text { per } \\
\text { minute }\end{array}$ & 2 & Visual & No spalling \\
\hline Martins et al & 100 & $150 \mathrm{~mm}$ cubic & $\begin{array}{c}\text { Ceramic } \\
\text { waste }\end{array}$ & $\begin{array}{c}1.5 \text { to } \\
2.5^{\circ} \mathrm{C} / \mathrm{min}\end{array}$ & 1 & Visual & $\begin{array}{l}\text { Minor spalling } \\
\text { when } \mathrm{T}>600^{\circ} \mathrm{C}\end{array}$ \\
\hline $\begin{array}{c}\text { Bodnóravá } \\
\text { et al. }\end{array}$ & 100 & $100 \times 300 \times 105$ & $\begin{array}{l}\text { Expanded } \\
\text { clay }\end{array}$ & ISO 834 & - & Visual & $\begin{array}{c}\text { Spalling when } \\
\mathrm{T}>700^{\circ} \mathrm{C}\end{array}$ \\
\hline
\end{tabular}

exposure temperature and even the test methodology used were very different and, therefore, it is difficult to carefully evaluate the results so as to compare them with the results of this research. Likewise, the characterization parameters considered important in the evaluation of the spalling phenomenon were not available. None of them contain information on parameters such as porosity, moisture content on the evaluation day, time and temperature of spalling, etc. It should also be emphasized that in most of these studies, the main objective was not even the evaluation of spalling, but the evaluation of the residual compressive strength of concrete after heating and subsequent cooling. Of the international studies presented, only the one by Bodnóravá et al. [34] focused on the evaluation of the phenomenon. However, in this work, the coarse aggregate used was expanded clay, different from the aggregate used in this research, making any attempts to compare the results unfeasible. In Martins et al [22], minor spalling was observed in some of the samples evaluated after heating to $600^{\circ} \mathrm{C}$, with subsequent cooling. The coarse aggregate employed was the same as the one used in this work; however, the geometry of the samples, the heating rate, the compressive strength of the mixture at room temperature and even the methodology of evaluation of spalling were very different from those of the present research. Evaluating any of these parameters in isolation, in the case of spalling, would only be feasible if they were at least somewhat similar.

Finally, the need to standardize the laboratory evaluation of the spalling of concrete at high temperatures should be emphasized. This standardization is necessary, as the parameters involved in the phenomenon are many, correlated and, therefore, difficult to evaluate in isolation.

\section{Conclusions}

Regarding the research presented here, it was found that:

a) At room temperature, as expected, replacing the conventional natural aggregate with the recycled ceramic aggregate causes mechanical strength to decrease, with compressive strength and the elastic modulus also decreasing the higher the percentage of substitution.

b) Replacing the natural coarse aggregate with red ceramic waste results in concretes that are more resistant to fire, i.e., the losses in compressive strength and elastic modulus for concretes with 40 and $100 \%$ of substitution are lower compared to the reference sample.

c) The results of reduction of mechanical strength (compressive strength and elastic modulus), with the increase in temperature, of concretes prepared with lightweight aggregates, were lower compared to the values recommended by ACI $216 \mathrm{R}-89$ [14]; therefore, it is suggested that these curves are adopted for the purpose of estimating the residual strength of national lightweight concretes, while results similar to those obtained in this work are not available.

d) Regarding the tendency to spalling, it can be verified that the concretes produced with red ceramic waste remained stable, as no spalling occurred even at temperatures above $800^{\circ} \mathrm{C}$.

e) Finally, the need to standardize the laboratory evaluation of the spalling of concrete at high temperatures should be emphasized. This standardization is necessary, as the parameters involved in the phenomenon are many, correlated and, therefore, difficult to evaluate in isolation.

f) The results of this work, unique in our country, should provide subsidies for a future understanding of the behavior of domestic lightweight concretes at high temperatures.

\section{Acknowledgments}

The authors thank Espaço da Escrita - Coordenadoria Geral da Universidade - UNICAMP - for the language services provided.

\section{Bibliographic references}

[1] RILEM TC 129-MHT. Recommendation of RILEM TC 129- 
MHT: Test Methods for Mechanical Properties of Concrete at High Temperatures - Compressive strength for service and accident conditions, V.28, p. 410-414, 1995. SOUZA, A.A.A; MORENO JR., A.L. Proposta de avaliação em laboratório do lascamento explosivo do concreto em situação de incêndio. Concreto \& Construção, v. 4, p. 96-103, 2010.

CAMPOS, M.A.; PAULON, V.A. Utilização de agregados alternativos de isoladores elétricos de porcelana em concretos. Concreto y Cemento. Investigación y Desarrollo, vol. 7 núm. 1, de la pág. 30 a la 43, Julio - Diciembre de 2015.

[4] JANKOVIC, K.; DRAGAN, N.; DRAGAN, B. Concrete paving blocks and flags made with crushed brick as aggregate. Construction and Building Materials 28: 659-663, 2012.

[5] MUELLER, A.; SCHNELL, A.; RUEBNER, K. The manufacture of lightweight aggregates from recycled masonry rubble. Construction and Building Materials 98: 376-387, 2015.

[6] AWOYERA, P.; AKINMUSURU, J. O.; NDAMBUKI, J.M. Green concrete production with ceramic wastes and laterite, Construction and Building Materials 117: 29-36, 2016.

[7] ZHOU, C.; CHEN, Z. Mechanical properties of recycled concrete made with different types of coarse aggregate. Construction and Building Materials 134: 497-506, 2017.

[8] DERRICK J. ANDERSON; SCOTT T. SMITH; FRANCIS T.K. AU. "Mechanical properties of concrete utilising waste ceramic as coarse aggregate". Construction and Building Materials 117 (2016) 20-28.

[9] MELICEVIC, I..;BJEGOVIC, D.; SIDDIQUE, Experimental research of concrete floor blocks with crushed bricks and tiles aggregate. Construction and Building Materials, 94, 775-783, 2015.

[10] CÁNOVAS, M.F. Patologia e Terapia do Concreto Armado. 522 p. São Paulo: PINI, 1988.

[11] MEHTA, P. K.; MONTEIRO, P. J. M. Concreto: Microestrutura, propriedades e materiais. 2. ed. São Paulo: IBRACON, 2014

[12] NEVILLE, A. M. Propriedades do concreto. $2^{\mathrm{a}}$ Edição. Ed. PINI. São Paulo, 1997.

[13] ASSOCIAÇÃO BRASILEIRA DE NORMAS TÉCNICAS. ABNT NBR 15200. Projeto de estruturas de concreto em situação de incêndio. Rio de Janeiro, 2012.

[14] AMERICAN CONCRETE INSTITUTE. (ACI). Guide for Determining the Fire Endurance of Concrete Elements. ACl 216R-89. ACI. New York, 1996.

[15] EUROPEAN COMMITTEE FOR STANDARDIZATION. EN 1991-1-2. Eurocode 1: Actions on structures - Part 1-2: General actions - Actions on structures exposed to fire. CEN, Bruxelas, 2002.

[16] SOLLERO, M.B.S.; MORENO JR., A.L. Post-Fire Residual Mechanical Properties of High Strength Concrete (HSC) Made with Basalt Aggregate. 9th International Conference on Structures in Fire (SIF),Princeton Univ, Princeton, JUN 08-10, 2016.

[17] ALMEIDA, J. M. A. Comportamento em altas temperaturas e na reidratação do concreto convencional e não convencional com cinza de casca de arroz. Tese
(Doutorado) - Programa de Pós-Graduação em Engenharia Civil, Universidade Federal do Rio Grande do Sul. Porto Alegre, 2017.

[18] SOUZA, A. A. A. ; MORENO JR, A.L. . Assessment of the influence of the type of aggregates and reydration on concrete submitted to high temperatures. Revista IBRACON de Estruturas e Materiais , v. 3, p. 477-493, 2010.

[19] INTERNATIONAL ORGANIZATION FOR STANDARDIZATION. Fire Resistance Tests - Elements of Building Construction. Part 1: General Requirements. ISO 834. Geneva, 2014.

[20] LANEYRIE, C.; BEAUCOUR, A.L.; GREEN, M.F.; HEBERT, R.L.; LEDESERT, B.; NOUMOWE, A. Influence of recycled coarse aggregates on normal and high performance concrete subjected to elevated temperatures. Construction and Building Materials 111, 368-378, 2016.

[21] TORIC, N.; BOKO, I.; JURADIN, S.; BALOEVIC, G. Mechanical properties of lightweight concrete after fire exposure. Structural Concrete 17, No. 6, 2016.

[22] MARTINS, D.J.; CORREIA, J.R.; BRITO, J. The effect of high temperature on the residual mechanical performance of concrete made with recycled ceramic coarse aggregates. Fire and Materials, Fire Mater; 40:289-304, 2016.

[23] RAJAWAT, D.;SIDDIQUE, S.;SHRIVASTAVA, S;CHAUDHARY, S.;GUPTA,T. Influence of fine ceramic aggregates on the residual properties of concrete subjected to elevated temperature. Fire and Materials. 2018;1-9.

[24] YAN, R.; YANG, S.; GUO, M.Z.; POON, C.S. Comparative evaluation of fire resistance of partition wall blocks prepared with waste materials. Journal of Cleaner Production 182, 156-165, 2018.

[25] KRZEMIEŃ, K.; HAGER, I. Assessment of Concrete Susceptibility to Fire Spalling: A Report on the State-of-the-art in Testing Procedures. Procedia Engineering, Vol. 108, 2015, pp. 285-292, ISSN 1877-7058.

[26] KODUR, K. Properties of Concrete at Elevated Temperatures. ISRN Civil Engineering, vol. 2014, Article ID 468510, 15 p. doi:10.1155/2014/468510

[27] HERTZ, K. D.;SORENSEN, L. S. Test method for spalling of fire exposed concrete. Fire Safety Journal 2005; 40(5):466-476.

[28] HUISMANN, S.; WEISE, F.; MENG, B.; SCHNEIDER. U. Transient strain of high strength concrete at elevated temperatures and the impact of polypropylene fibers. Material and Structures.vol. 45,issue 5, 2012, pp. 793-801.

[29] HAN, C. G.; HWANG, Y. S.; YANG, S. H.; GOWRIPALAN, $\mathrm{N}$. Performance of spalling resistance of high performance concretewith polypropylene fiber contents and lateral confinement. Cement and Concrete Research 2005; 35:1747-1753.

[30] HAN C. G., HAN M. C., HEO, Y. S. Improvement of residual compressive strength and spalling resistance of high-strengthRC columns subject to fire. Construction and Building Materials 2009; 23:107-116.

[31] HERTZ, K. D.;SØRENSEN, L. S. Test method for spalling of fire exposed concrete. Fire Safety Journal 2005; 40(5):466-476. 
[32] HERTZ, K. D. Limits of spalling of fire-exposed concrete. Fire Safety Journal 2003; 38(2):103-116.

[33] HE, K. C.; GUO, R. X.; MA, Q. M.; YAN, F.; LIN, Z.W.; SUN, Y L. Experimental Research on High Temperature Resistance of Modified Lightweight Concrete after Exposure to Elevated Temperatures. Hindawi Publishing Corporation Advances in Materials Science and Engineering, Article ID 5972570, 2016.

[34] BODNÁROVÁ, L.; HELA, R.; HUBERTOVÁ, M.; NOVÁKOVÁ, I. Behavior of Lightweight Expanded Clay Aggregate Concrete Exposed to High Temperatures. World Academy of Science, Engineering and Technology International Journal of Civil, Architectural, Structural and Construction Engineering Vol: 8 No:12, 2014.

[35] ASSOCIAÇÃO BRASILEIRA DE NORMAS TÉCNICAS. NBR NM 53: Agregado graúdo -Determinação da massa específica, massa específica aparente e absorção de água. Rio de Janeiro, jul. 2003.

[36] ASSOCIAÇÃO BRASILEIRA DE NORMAS TÉCNICAS. NBR NM 52: Agregado miúdo. -Determinação da massa específica e massa específica aparente. Rio de Janeiro, jul. 2002.

[37] ASSOCIAÇÃO BRASILEIRA DE NORMAS TÉCNICAS. NBR NM 30: Agregado miúdo - Determinação da absorção de água. Rio de Janeiro, jul. 2001.

[38] ASSOCIAÇÃO BRASILEIRA DE NORMAS TÉCNICAS. NBR NM 45: Agregados - Determinação da massa unitária e do volume de vazios. Rio de Janeiro, mar. 2006.

[39] ASSOCIAÇÃO BRASILEIRA DE NORMAS TÉCNICAS. NBR NM 248: Agregados. Determinação da composição granulométrica. Rio de Janeiro, jul. 2003.

[40] ASSOCIAÇÃO BRASILEIRA DE NORMAS TÉCNICAS. NBR NM 46. Agregados - Determinação do material fino que passa através da peneira $75 \mu \mathrm{m}$, por lavagem. Rio de Janeiro, jul. 2003.

[41] ASSOCIAÇÃO BRASILEIRA DE NORMAS TÉCNICAS. NBR 7218: Agregados - Determinação do teor de argila em torrões e materiais friáveis. Rio de Janeiro, agosto 1987.

[42] RILEM TC 129-MHT. Test methods for mechanical properties of concrete at high temperatures - Compressive strength for service and accident conditions. Materials and Structures, [s.I.], V.28, p. 410-414, 1995.

[43] RILEM TC 129-MHT. Test methods for mechanical properties of concrete at high temperatures - Modulus of elasticity for service and accident conditions. Materials and Structures, [s.I.], V.37, p. 139-144, mar.2004. 